\section{TUMBUHAN OBAT DESA PELAWAN}

Kecenderungan masyarakat yang mengandalkan obat kimia tentu saja lambat laun akan memberikan efek samping yang berbahya pada tumbuh dan kesadaran itu kini menjadikan masyarakat ingin kembali ke alam "Back to Nature" dalam menjaga kebugaran. Pemanfaatan tumbuhan telah digunakan secara turun temurun sebagai sumber obat tradisional dalam mengatasi berbagai sumber penyakit sebelum perkembangan ilmu dan teknologi sesemutahir seperti saat ini. Penggunaan obat tradisional bergantung pada sumber daya alam sekitar dengan mengedepankan kearifan lokal. Obat tradisional adalah obat-obatan yang diolah secara tradisional, turun-temurun, berdasarkan resep nenek moyang, adat istiadat, kepercayaan atau kebisaaan setempat baik bersifat gaib maupun pengetahuan tradisional yang berlangsung selama berabad-abad. Dalam buku ini diuraikan manfaat dan kegunaan potensi jenis tumbuhan obat yang ada dilingkungan sekitar sekaligus mengenalkan pada generasi milineal mengenai keanekaragaman hayati pada tumbuhan obat yang ada di Desa Pelawan. Buku ini juga memiliki informasi mengenai nama ilmiah, farmakologis, kegunaan, dan cara sederhana proses peracikannya.

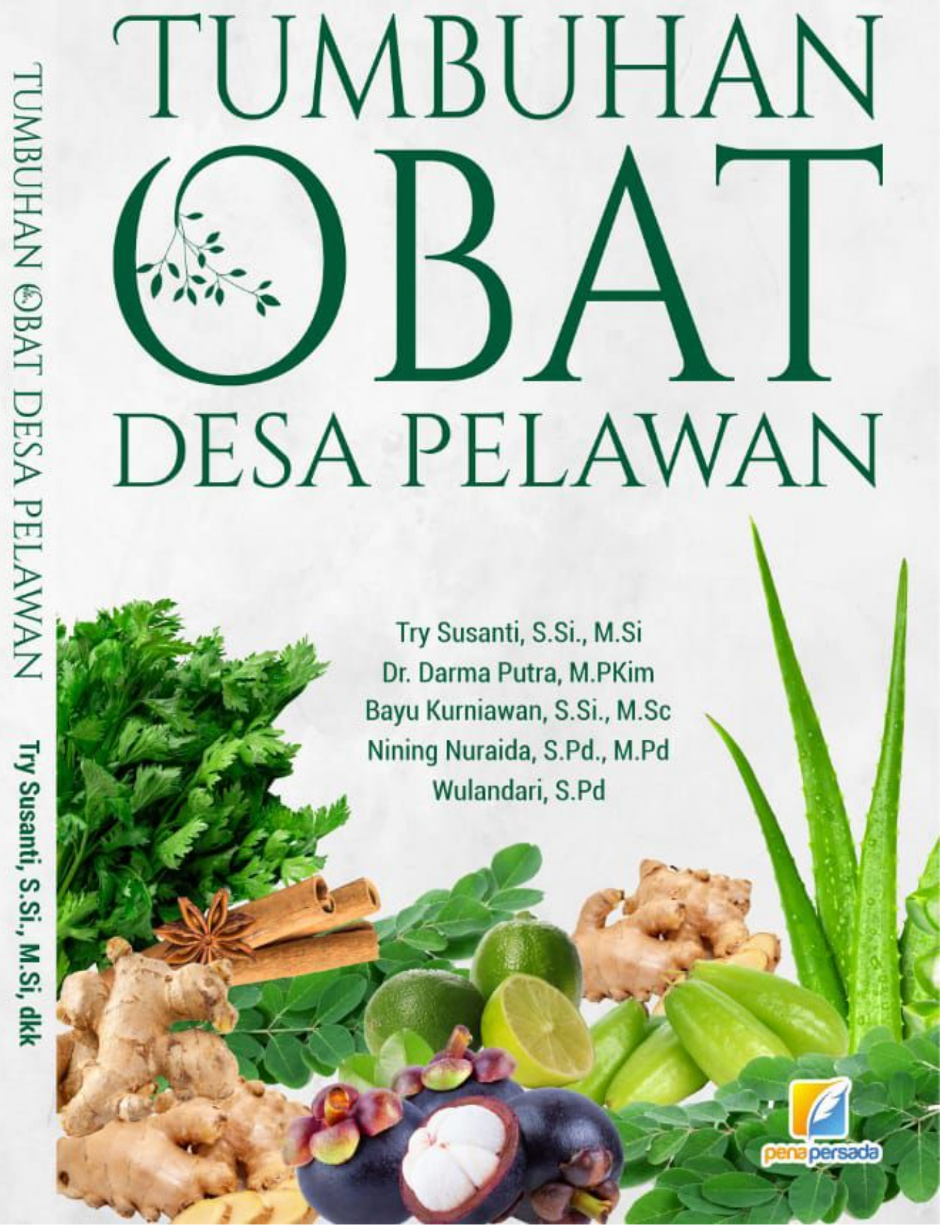




\section{TUMBUHAN OBAT DESA PELAWAN}

TRY SUSANTI, S.Si., M.Si

Dr. DARMA PUTRA, M.PKim

BAYU KURNIAWAN, S.Si., M.Sc

NINING NURAIDA, S.Pd., M.Pd

WULANDARI, S.Pd

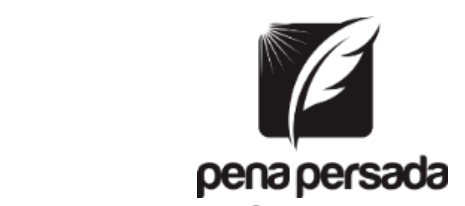

PENERBIT CV. PENA PERSADA

TUMBUHAN OBAT DESA PELAWAN 


\title{
Penulis:
}

Try Susanti, S.Si., M.Si

Dr. Darma Putra, M.PKim

Bayu Kurniawan, S.Si., M.Sc

Nining Nuraida, S.Pd., M.Pd

Wulandari, S.Pd

ISBN : 978-623-315-197-9

\author{
Editor: \\ Iskandar, S.Ag., M.Pd., M.S.I., Ph.D
}

Design Cover :

Retnani Nur Briliant

Layout :

Eka Safitry

\section{Penerbit CV. Pena Persada}

Redaksi :

Jl. Gerilya No. 292 Purwokerto Selatan, Kab. Banyumas

Jawa Tengah

Email : penerbit.penapersada@gmail.com

Website : penapersada.com Phone : (0281) 7771388

Anggota IKAPI

All right reserved

Cetakan pertama : 2021

Hak Cipta dilindungi oleh undang-undang. Dilarang memperbanyak karya tulis ini dalam bentuk apapun tanpa izin penerbit 


\section{KATA PENGANTAR}

Puji syukur kehadirat Allah S.W.T, yang telah menganugrahkan keanekargaman hayati tumbuhan obat ini. Bimbingan dan bantuan dari berbagai pihak, kami mengucapkan terimakasih telah terselesainya tulisan ini.

Indonesia berada di wilayah tropis yang memiliki salah satu hutan terluas dengan biodiversitasnya yang sangat melimpah di dunia yang terhampar di daratan katulistiwa dari sabang sampai merauke. Hutan menyimpan kekayaan jenis tumbuhan dan telah di temukan lebih dari 30.000 jenis tumbuhan dan 400 spesies diantaraanya memiliki nilai ekonomi yang sangat tinggi. Sebanyak $26 \%$ telah di manfaatkan dan $74 \%$ diantaranya masih belum dimanfaatkan secara ekonomi. Sebanyak 8000 spesies diketahui memiliki potensi obat dan 800-1200 spesies digunakan oleh masyarakat luas sebagai obat tradisional dan kosmetik. Buku ini menyajikan data mengenai tumbuhan potensi obat dan pemanfaatannya di Desa Pelawan, Kecamatan Pelawan, Kabupaten Sarolangun, Provinsi Jambi. 


\section{DAFTAR ISI}

KATA PENGANTAR ................................................................... iii

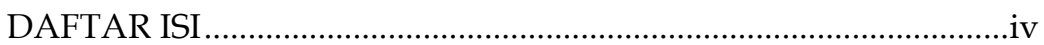

BAB I PENDAHULUAN ............................................................. 1

A. Keanekaragaman Hayati Indonesia ........................................ 1

B. Tumbuhan Sebagai Obat Tradisional .......................................2

BAB II TANAMAN OBAT TRADISIONAL .....................................5

A. Tanaman Obat..................................................................... 5

B. Jenis obat tradisional .............................................................6

C. Sumber perolehan obat tradisional ........................................ 7

D. Identifikasi Tumbuhan ...........................................................9

BAB III JENIS TUMBUHAN POTENSI OBAT ................................ 11

A. Sirih merah....................................................................... 133

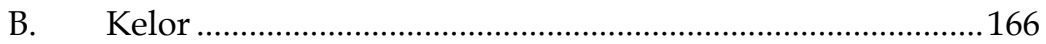

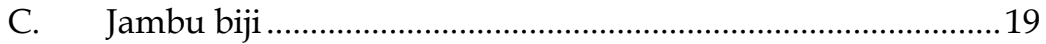

D. Jeruk nipis........................................................................ 233

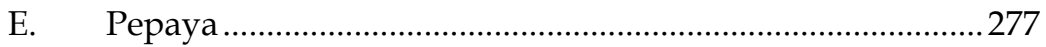

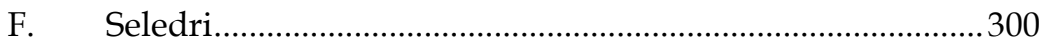

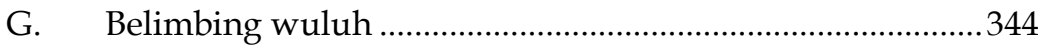

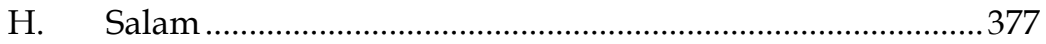

I. Cocor bebek ..................................................................... 41

J. Kumis kucing ............................................................... 444

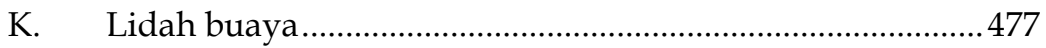

L. Sirsak ....................................................................................50

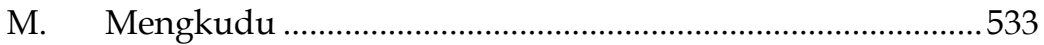

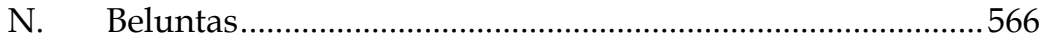

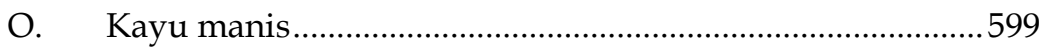

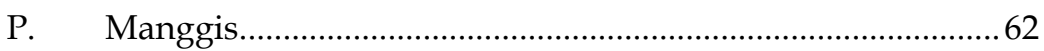

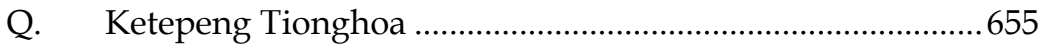

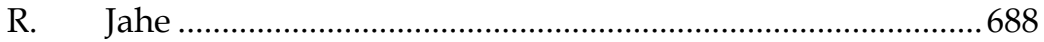

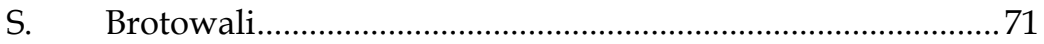

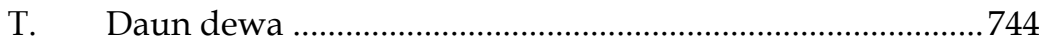

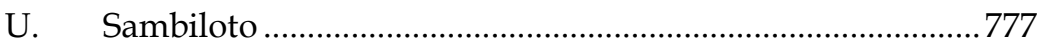

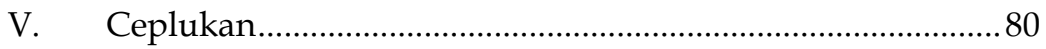

W. Kayu putih..................................................................... 83 
BAB IV BAGIAN TUMBUHAN SEBAGAI OBAT TRADISIONAL .866

A. Bagian tumbuhan yang digunakan sebagai obat Tradisional . .866

B. Pemanfataan Obat Tradisional Secara Turun Temurun.....888

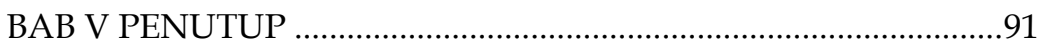

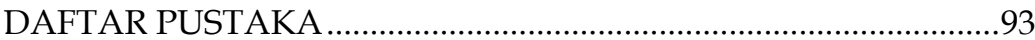




\section{TUMBUHAN OBAT DESA PELAWAN}




\section{BAB I \\ PENDAHULUAN}

\section{A. Keanekaragaman Hayati Indonesia}

Indonesia salah satu negara Megabiodiversitas dengan wilayah didaerah garis katulistiwa yang mempunyai hutan hujan tropis yang sangat luas. Hal ini berdampak pada tingginya keaenaragaman flora dan fauna endemik Indonesia. keanekaragama ini bersumber dari keanearagaman gen, spesies, dan ekosistem.

Keanekaragaman flora telah tersurah didalam alQur'an sebagai bukti kebesaran Allah SWT. Hal ini dapat dijadikan bukti untuk menambah dan meningkatkan keimanan kita terhadap Allah SWT, dimana telah di firmankan oleh Allah SWT dalam kitab-Nya Surat Thaha: Ayat 53

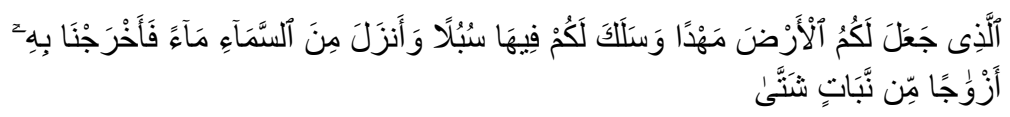

Artinya : "Yang telah menjadikan bagimu bumi sebagai hamparan dan Yang telah menjadikan bagimu di bumi itu jalan-jalan, dan menurunkan dari langit air hujan. Maka Kami tumbuhkan dengan air hujan itu berjenis-jenis dari tumbuhtumbuhan yang bermacam-macam".

Ayat di atas menjelaskan bahwa tumbuhan sebagai makhluk yang di ciptakan Allah SWT di bumi dengan berbagai jenis tumbuhan yang beranekaragam yaitu ada yang hitam dan putih, berbeda warna, rasa, dan manfaatnya dalam kehidupan sehari-hari.

Flora yang di artikan sebagai tumbuhan yang tumbuh di suatu habitat tertentu. Apabila istilah flora ini di kaitkan dengan life-form (bentuk hidup atau habitus) tumbuhan, maka terbagi menjadi flora pohon (flora berbentuk pohon), flora semak belukar, flora rumput, dan sebagainya. Apabila istilah 
flora ini dikaitkan dengan nama tempat, maka akan muncul istilah-seperti flora jawa, flora Gunung halimun, dan sebagainya.

\section{B. Tumbuhan Sebagai Obat Tradisional}

Tumbuhan merupakan keanekaragaman hayati yang selalu ada di sekitar kita, baik yang tumbuh secara liar atau yang sudah di budidayakan. Umumnya tumbuhan yang memiliki khasiat obat yang dapat menyembuhkan penyakit fisik maupun penyakit dalam mudah di temukan, karena tumbuh di perkarangan rumah, kebun, dan hutan. Selain itu juga kita konsumsi sebagai pelengkap nutrisi yakni sayuran dan buah maupun bahan pelengkap masakan.

Dalam tumbuhan terdapat gudang bahan kimia yang paling lengkap. Berpuluh-puluh, bahkan mungkin beribu-ribu komponen kimia terkandung di dalam tanaman, sehingga banyak tanaman yang digunakan sebagai jamu atau obat tradisional. Obat tradisional adalah ramuan dari berbagai jenis bagian tanaman yang mempunyai khasiat menyembuhkan berbagai macam penyakit yang sudah di lakukan sejak zaman dahulu. Obat tradisonal sendiri masih mempunyai beragam variasi dari senyawa, sehingga obat tradisional mungkin terjadi dengan adanya interaksi antar senyawa yang mempunyai pengaruh lebih kuat untuk proses penyembuhan penyakit.

Tumbuhan obat adalah semua jenis tumbuhan tanaman yang menghasilkan satu atau lebih komponen aktif yang digunakan untuk perawatan kesehatan dan pengobatan atau seluruh spesies tumbuhan yang di ketahui atau di percaya mempunyai khasiat obat. Tumbuhan obat tradisional di Indonesia mempunyai peranan yang sangat penting terutama bagi masyarakat di daerah pedesaan yang fasilitas kesehatannya masih sangat terbatas dan biaya kesehatan yang cukup mahal.

Tradisi pengobatan suatu masyarakat tidak terlepas dari kaitan budaya setempat. Persepsi mengenai konsep sakit, 
sehat, dan keragaman jenis tumbuhan yang digunakan sebagai obat tradisional terbentuk melalui proses sosialisasi yang secara turun temurun di percayai dan diyakini kebenarannya. Penggunaan bahan alami di Indonesia, baik sebagai obat maupun tujuan lain cenderung meningkat, terlebih dengan adanya isu back to nature serta krisis berkepanjangan yang mengakibatkan turunnya daya beli masyarakat. Penggunaan obat tradisional (obat herbal) banyak di gunakan masyarakat menengah ke bawah yang di pergunakan sebagai obat penyakit, kosmetika, dan upaya pencegahan penyakit (preventif), penyembuhan (kuratif), pemulihan kesehatan (rehabilitatif) serta peningkatan kesehatan (promotif).

Kondisi masyarakat Desa Pelawan secara umum dalam perekonomian berada di taraf menengah dalam artian berkecukupan, yang hanya sebatas untuk keperluan pokok seperti kebutuhan makan sehari-hari dan tempat tinggal. Masyarakat Desa Pelawan mata pencariannya rata-rata bercocok tanam (bersawah, berkebun) dan ibu rumah tangga, karena sebagian besar masyarakat hidup bergantung dari hasil bumi dan kondisi alam, kemudian lapangan pekerjaan di Desa Pelawan sangat minim.

Penggunaan tumbuhan sebagai obat tradisional juga di minati oleh masyarakat Desa Pelawan Kecamatan Pelawan Kabupaten Sarolangun karena telah terbukti bahwa obat yang berasal dari tumbuhan lebih menyehatkan dan tanpa menimbulkan adanya efek samping jika di bandingkan obatobatan yang berasal dari bahan kimia, di samping harganya yang relatif terjangkau tanaman obat ini juga mudah di temukan di perkarangan atau di perkebunan masyarakat Desa Pelawan Kecamatan Pelawan.

Koleksi tumbuhan obat ini dilakukan dengan cara observasi dengan melihat jenis tanaman obat tradisional yang ada di Desa Pelawan. Kemudian, juga menggunakan metode wawancara kepada masyarakat Desa Pelawan terpilih berdasarkan kriteria tertentu yaitu tabib, dukun, para cendekiawan, dan tokoh adat. 
Tumbuhan yang sering di gunakan oleh masyarakat sebagai obat tradisional di Desa Pelawan yaitu tanaman sirsak (Annona muricata L.), bagian yang di ambil untuk obat tradisional yaitu daun. Daun sirsak mengandung senyawa acetogenin, minyak esensial, reticuline, dan higenamine. Daun sirsak ini dapat membantu mengobati asam urat dan kencing manis. Cara pengolahannya yaitu dengan cara menyiapkan 1015 lembar daun sirsak kemudian cuci bersih daun sirsak dengan air yang mengalir. Selanjutnya panaskan air sebanyak 2 gelas lalu masukkan daun sirsak dan tunggu hingga menguap dan tersisa air rebusan sebanyak 1 gelas kemudian diminum.

Dalam pengobatan tradisional yang menggunakan "tabas-tabas" (mantra) yang diperantararai oleh dukun, pada umumnya dalam pelaksanaanya menggunakan tumbuhan obat sebagai pelengkap pelaksanaan pengobatan, pengetahuan pengobatan tradisional tersebut jika tidak ditulis lama kelamaan akan hilang dan pengetahuan masyarakat tentang tumbuhan obat juga akan menghilang secara perlahan.

Berdasarkan uraian diatas, penulis melakukan kajian mengenai jenis tumbuhan apa saja yang di gunakan untuk pengobatan di Desa Pelawan Kecamatan Pelawan Kabupaten Sarolangun. 


\section{BAB II \\ TANAMAN OBAT TRADISIONAL}

\section{A. Tanaman Obat}

Obat tradisional dalam UU No.23 tahun 1992 adalah bahan atau ramuan bahan yang berupa bahan tumbuhan, bahan hewan, bahan mineral, sediaan sarian (galenik) atau campuran dari bahan tersebut yang secara turun-temurun telah digunakan untuk pengobatan berdasarkan pengalaman..

Obat tradisional banyak digunakan oleh masyarakat adat yang diturunkan secara turun temurun. Pemanfaatan obat tradisional sebagai upaya preventif dalam upaya menjaga kesehatan dan sebagai obat penyakit tertentu.

Tumbuhan obat adalah tumbuhan yang mengandung zat aktif tertentu pada sebagian atau keseluruhan dari bagian tumbuan yang berupa akar, batang, daun, ataupun buah yang dapat di manfaatkan secara tradisional oleh masyarakat adat dengan cara proses perebusan, tumbuk, diperas, parut, dan atau diperas dari hasil racikan yang dapat dijadikan sebagai penyembuh penyakit atau obat tertentu. Obat hasil olahan ini penggunaannya dengan cara diminum, oles, ataupun digosokkan.

Perkembangan ilmu pengetahuan dan teknologi, tumbuhan obat dapat di kaji lebih mendalam melalui bidang keilmuan farmakologi dan ilmu etnobotani. Farmakologi mengkaji mengenai kerja obat dalam tubuh seperti mekanisme obat dan juga interaksi serta khasiat obat pada tubuh. Farmakognosi merupakan kajian mengenai obat yang berasal dari tanaman, mineral dan hewan atau biasa di sebut sebagai ilmu herbal. Sedangkan, etnobotani mengarah kepada sasaran untuk mengembangkan sistem pengetahuan masyarakat lokal terhadap tanaman obat sehingga dapat menemukan senyawa kimia baru yang berguna dalam pembuatan obat-obatan modern untuk menyembuhkan penyakit-penyakit berbahaya 
pada manusia. Pada prinsipnya kedua pendekatan tersebut berperan dalam mengeksplorasi jenis dan pemanfaatan tumbuhan berkhasiat obat yang di manfaatkan manusia (etnofarmakologi).

\section{B. Jenis obat tradisional}

Menurut Kepala Badan BPOM RI No. HK.00.05.4.2411 tentang ketentuan pokok pengelompokkan dan penandaan obat bahan alam Indonesia, obat tradisional dibagi menjadi beberapa yaitu jamu, obat herbal terstandar, dan fitofarmaka.

1. Jamu (Emprical Based Herbal Medicine)

Jamu adalah obat tradisional yang berisi seluruh bahan tanaman yang menjadi penyusu jamu tersebut. Jamu disajikan secara tradisional dalam bentuk serbuk seduhan, pil, atau cairan. Umumnya, obat tradisional ini dibuat dengan mengacu pada resep peninggalan leluhur. Satu jenis jamu disusun dari berbagai tanaman obat yang jumlahnya antara 5-10 macam, bahkan bisa lebih. Jamu tidak memerlukan pembuktian ilmiah sampai uji klinis, tetapi cukup dengan bukti empiris. Di samping klaim khasiat yang dibuktikan secara empiris, jamu juga harus memenuhi persyaratan keamanan dan standar mutu. Jamu yang telah digunakan secara turun menurun selama berpuluh-puluh tahun bahkan ratusan tahun telah membuktikan keamanan dan manfaat secara langsung untuk tujuan kesehatan tertentu.

Jamu merupakan produk herbal yang memanfaatkan tumbuhan asli Indonesia. Konsep jamu hasil kearifan manusia dan lingkungan alam disekitarnya sehingga menghasilkan konsep-konsep yang unik dalam kaitannya dengan pemeliharaan kesehatan dan kecantikan selaras dengan siklus hidup perkembangan manusia.

2. Obat herbal terstandar (Standarized Based Herbal Medicine)

Obat herbal terstandar merupakan obat tradisional yang disajikan dari hasil ekstraksi atau penyaringan bahan 
alam, baik tanaman obat, binatang, maupun mineral. Dalam proses pembuatannya, dibutuhkan peralatan yang tidak sederhana dan lebih mahal dari pada jamu. Tenaga kerjanyapun harus didukung oleh pengetahuan dan keterampilan membuat ekstrak. Obat herbal ini umumnya di tunjang oleh pembuktian ilmiah berupa penelitian praklinis. Kajian ini meliputi standardisasi kandungan senyawa berkhasiat dalam bahan penyusun, satndardisasi pembuatan ekstrak yang higienis, serta uji toksisitas akut maupun kronis.

3. Fitofarmaka (Clinical Based Herbal Medicine)

Fitofarmaka merupakan obat tradisional yang dapat disejajarkan dengan obat modern. Proses pembuatannnya telah terstandar dan ditunjang oleh bukti ilmiah sampai uji klinis pada manusia. Karena itu, dalam pembuatannya diperlukan peralatan bioteknologi modern, tenaga ahli, dan biaya yang tidak sedikit.

\section{Sumber perolehan obat tradisional}

1. Obat tradisional buatan sendiri

Adat istiadat yang diwariskan secara turun temurun mempunyai kemampuan untuk meracik ramuan obat tradisional. Hasil pemikiran dan kerarifan lokal masarakat dalam perkembangan pengetahuan dikembangkan dalam program taman obat keluarga (toga).

Toga menekankan pada self care untuk menjaga kesehatan anggota keluarga serta untuk menangani penyakit ringan sebagai usaha preventif keluarga. Sumber tanaman toga berasal dari koleksi secara individu, keluarga, maupun kolektif dalam suatu lingkungan masyarakat..

2. Obat tradisional dari pembuat jamu (Herbalis)

a. Jamu gendong

Obat tradisional yang paling mudah ditemui adalah penjual jamu gendong. Penjual obat Jamu gendong tersebar diseluruh nusantara tidak hanya 
popular di pulau Jawa.

Obat yang tersedia dari penjual jamu gendong diantaranya adalah kunyit asam, mengkudu, pahitan, beras kencur, cabe puyang, dan gepyokan. Selain itu, penyediaan jamu gendong dapat dilakukan dengan pemesanan khusus sesuai dengan kebutuhan misalnya jamu bersalin dan jamu khusus sesuai pesanan, misalnya jamu bersalin dan jamu untuk mengobati keputihan. Dengan adanya industri jamu bersalin dan jamu, kini penjual jamu gendong sering kali juga menyediakan jamu berupa serbuk yang dikonsumsi bersamaan dengan jamu gendong.

b. Peracik jamu

Selain jamu gendong, dipasar-pasar tradisional di jawa tengah juga masih dijumpai peracik jamu tradisional. Bentuk jamu menyerupai jamu gendong, tetapi kegunaannya lebih khusus untuk keluhan kesehatan tertentu, misalnya untuk kesegaran, menghilangkan pegal dan linu, serta batuk. Peracik jamu tradisional seperti ini memang sudah semakin berkurang. Mungkin karena kalah bersaing dengan industri besar yang mampu menyediakan jamu dalam bentuk yang lebih praktis.

c. Obat tradisional dari tabib

Meskipun jumlahnya tidak banyak, tabib masih bisa dijumpai. Dalam praktik pengobatannya, tabib menyediakan ramuan yang berasal dari bahan alam local. Selain memberikan ramuan, para tabib umumnya juga mengombinasikan dengan teknik lain seperti metode spiritual atau supranatural. Ilmu ketabiban umumnya diperoleh dengan cara bekerja sambil belajar kepada tabib yang telah lama berpraktik. Di beberapa kota, telah dijumpai pendidikan atau kursus ketabiban yang dikelola dan diselenggarakan dengan baik oleh tabib tertentu.

d. Obat tradisional dari Shines 
Shinse adalah pengobat dari etnis Tionghoa yang mengobati pasien dengan menggunakan obat tradisional. Pengetahuan tentang pengobatan shines berasal dari Negara asal mereka yaitu Tionghoa. Umumnya bahan- bahan yang digunakan berasal dari Tionghoa. Namun, tidak jarang pula yang dicampur dengan bahan lokal yang sejenis dengan yang dijumpai di Tionghoa.

Obat tradisional Tionghoa berkembang baik diindonesia dan banyak diimpor. Tidak hanya untuk memenuhi kebutuhan pasien etnis Tionghoa, tetapi obat tradisional itu juga dikonsumsi oleh masyarakat pribumi. Obat tradisional Tionghoa mudah diperoleh di toko-toko obat Tionghoa yang menyediakan sediaan jadi dan menerima peracikan resep dari shines. Dalam pengobatannya, shines biasanya mengkombinasikan ramuan dengan teknik pijatan

\section{Identifikasi Tumbuhan}

Identifikasi tumbuhan merupaka pengelompokkan jenis tumbuhan berdasarkan karakter morfologi dengan sifat yang sama antara tumbuhan tersebut yang dalam hal ini menentukan namanya yang benar dan tempatnya yang tepat dalam sistem klasifikasi binomial nomenklatur. Untuk istilah identifikasi sering juga digunakan istilah deteminasi.

Ada beberapa cara dalam mengidentifiksi diantaranya sebagai berikut:

1. Ingatan identifikasi dilakukan berdasarkan pengalaman atau ingatan.

2. Bantuan orang, identifikasi dapat dilakukan dengan meminta bantuan para ahli botani sistematik.

3. Specimen acuan, identifikasi dilakukan dengan membandingkan secara langsung menggunakan spesimen acuan yang bisa diberikan etiket bertulisan nama jenisnya.

Pustaka identifikasi dilakukan dengan membandingkan dan mencocokkan ciri-ciri tumbuhan yang akan diidentifikasikan dengan gambar yang ada di pustaka. 
Pertolaan umumnya bersifat tehnik berupa hasil penelitian yang di sajikan dalam bentuk, monografi, revisi, flora, bukubuku pegangan atau bentuk lainnya. 


\section{BAB III \\ JENIS TUMBUHAN YANG DI GUNAKAN SEBAGAI OBAT}

Berdasarkan wawancara dengan 10 responden yang terdiri dari dukun yang sering memanfaatkan tumbuhan sebagai obat tradisional dan masyarakat umum di Desa Pelawan Kecamatan Pelawan Kabupaten Sarolangun yang menggunakan tumbuhan obat sebagai obat tradisional, di dapatkan 23 jenis tumbuhan yang digunakan sebagai bahan obat-obatan.

Banyaknya jenis tumbuhan obat yang di temukan di Desa Pelawan Kecamatan Pelawan Kabupaten Sarolangun ini lebih banyak di bandingkan dengan penelitian Sri Hartati, (2013) yang menemukan sebanyak 22 jenis tumbuhan obat di Desa Kuamang Kecamatan VII Koto Kabupaten Tebo. Tumbuhan obat yang penulis temukan antara lain :

Tabel 1 Jenis tumbuhan dan manfaatnya :

\begin{tabular}{|c|c|c|c|}
\hline No & Local name & Family & Scientific name \\
\hline 1 & Sirih merah & Piperaceae & Piper crocatum Ruiz \& Pav \\
\hline 2 & Kelor & Moringaceae & Moringa oliefera Lam. \\
\hline 3 & Jambu biji & Myrtaceae & Psidium guajava L. \\
\hline 4 & Jeruk nipis & Rutaceae & Citrus aurantifolia L. \\
\hline 5 & Papaya & Cariceae & Carica papaya L. \\
\hline 6 & Seledri & Apiaceae & Apium graveolens L. \\
\hline 7 & $\begin{array}{l}\text { Belimbing } \\
\text { wuluh }\end{array}$ & Oxalidaceae & Averhoa bilimbi L. \\
\hline 8 & Salam & Mytrtaceae & $\begin{array}{l}\text { Syzygium Polyanthum } \\
\text { (Wight) Walp }\end{array}$ \\
\hline 9 & $\begin{array}{l}\text { Cocor } \\
\text { bebek }\end{array}$ & Crassulaceae & Kalanchoe pinnata L. \\
\hline 10 & Kumis kucing & Lamiaceae & $\begin{array}{l}\text { Orthosiphon staminesis } \\
\text { Benth. }\end{array}$ \\
\hline
\end{tabular}




\begin{tabular}{|c|c|c|c|}
\hline No & Local name & Family & Scientific name \\
\hline 11 & $\begin{array}{l}\text { Lidah } \\
\text { buaya }\end{array}$ & Liliceae & Aloe vera (L.) Burm \\
\hline 12 & Sirsak & Annovaceae & Annona muricata L. \\
\hline 13 & Mengkudu & Rubiaceae & $\begin{array}{c}\text { Morinda } \\
\text { citrifolia L. }\end{array}$ \\
\hline 14 & $\begin{array}{c}\text { Beluntas, kayu } \\
\text { putih }\end{array}$ & Asteraceae & Pluchea indica (L) Less. \\
\hline 15 & $\begin{array}{l}\text { Kayu } \\
\text { manis }\end{array}$ & Lauraceae & $\begin{array}{l}\text { Cinnamomum burmanii } \\
\text { Nees \& T. Nees. }\end{array}$ \\
\hline 16 & Manggis & Cluciaceae & Garcinia mangostana L. \\
\hline 17 & $\begin{array}{l}\text { Ketepeng } \\
\text { Tionghoa }\end{array}$ & Fabaceae & Cassia alata $\mathrm{L}$. \\
\hline 18 & Jahe & Zingiberaceae & Zingiber officinale \\
\hline 19 & Brotowali & Menispermaceae & Tinospora rhumpii L. \\
\hline 20 & Daun dewa & Compositae & $\begin{array}{c}\begin{array}{c}\text { Gynura procumbens (Lour.) } \\
\text { Merr }\end{array} \\
\end{array}$ \\
\hline 21 & Meniran & Euphorbiaceae & $\begin{array}{l}\text { Andrographis paniculata } \\
\text { (Burm. fil.) Nees. }\end{array}$ \\
\hline 22 & Sambiloto & Acanthaceae & Physalis minima L. \\
\hline 23 & Ceplukan & Solonaceae & Melaleuca leucadendra L. \\
\hline
\end{tabular}




\section{A. Sirih merah}

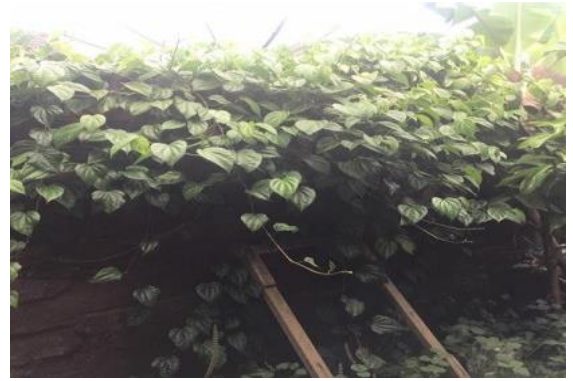

Gambar 1. Sirih merah (Piper crocatum Ruiz \& Pav.)

(Sumber : Dokumen pribadi)

1. Klasifikasi ilmiah tumbuhan

Kingdom

: Plantae

Divisi

: Magnoliophyta

Kelas

: Magnoliopsida

Ordo

: Piperales

Family

: Piperaceae

Genus

: Piper

Spesies

: Piper crocatum Ruiz \& Pav.

2. Deskripsi tumbuhan

Tanaman sirih (Piper, suku: Piperaceae) mrupakan jenis tanaman yang memiliki nilai estetik dan dapat dijadikan sebagai tanaman hias, sayuran, rempah-rempah, ramuan obat, maupun sebagai perlengkapan (uborampe) dalam upacara-upacara adat.

Karakteristik tanaman ini dapat digolongkan menjadi tanaman semak, batang bersulur dan beruas, yang memiliki ruas buku dengan jarak 5-10 cm, dan pada setiap buku tumbuh bakal akar. Karakter daun bertangkai, berbentuk ellips, acuminatus, sub acut pada basalnya dengan bagian atas meruncing, mengkilap, tepi rata atau tidak berbulu.

Panjang daun sirih berukuran 4-5 cm, daun bagian atas bewarna hijau tua dengan daerah sekitar tulang keperakan, dan bagian bawah bewarna ungu, daun 